\begin{tabular}{llrr}
\hline \hline Volume: & 3 & E-ISSN: & $2655-1942$ \\
Number: & 1 & Terbitan: & April 2020 \\
Page : & $1-14$ & & \\
\hline
\end{tabular}

\title{
Eksistensi Yurisprudensi Mahkamah Agung (MA) Dalam Penegakan Hukum Keluarga Islam Indonesia
}

\author{
Islamiyati $^{1}$, Ery Agus Priyono ${ }^{1}$, Dewi Hendrawati ${ }^{1}$, Achmad Arief Budiman ${ }^{2}$ \\ ${ }^{1}$ Fakultas Hukum Universitas Diponegoro Semarang \\ ${ }^{2}$ Universitas Islam Negeri Walisongo Semarang \\ Jl. Prof. Sudharto No. 1 Semarang \\ E-mail: Islamiyati@yahoo.co.id
}

\begin{abstract}
Abstrak
Pendapat kontra atas yurisprudensi hakim MA tentang hukum keluarga Islam sangat mengganggu eksistensi penegakaan keadilan, karena dasar hukumnya sering bertentangan dengan teks perundang-undangan. Penelitian menganalisis apakah dan sejauhmanakah yurisprudensi MA dapat menegakkan hukum keluarga Islam Indonesia. Jenis penelitian ini adalah library research (penelitian kepustakaan), data yang dibutuhkan data sekunder. Metode pendekatannya adalah yuridis doktrinal, dan data dianalisis secara kualitatif. Produk penelitian menerangkan bahwa yurisprudensi MA adalah salah satu produk pemikiran hukum Islam dari lembaga peradilan, hakim berperan penting menegakkan hukum Islam karena hakim tidak terlepas dari ijtihad untuk menemukan hukum melalui pemahaman dan pemaknaan UU. Eksistensi yurisprudensi digunakan dasar pertimbangan hukum hakim PA dalam menyelesaikan perkara, mampu mengukuhkan penguatan hukum dan penyelesaian problem hukum keluarga Islam secara adil dan benar berpijak pada prinsip dasar syariah Islam.
\end{abstract}

Kata Kunci: Yurisprudensi, Penegakan Hukum, Hukum Keluarga Islam

\begin{abstract}
The contradictory opinion of the MA judge's jurisprudence regarding Islamic family law seriously disturbs the existence of the enforcement of justice, because the legal basis is often in conflict with the text of the legislation. The research analyzes whether and to what extent MA MA jurisprudence can uphold Indonesian Islamic family law. This type of research is library research; the data needed secondary data. The method of approach is juridical doctrinal, and the data are analyzed qualitatively. The research product explains that MA jurisprudence is one of the products of Islamic legal thinking from the judiciary, judges play an essential role in upholding Islamic law because judges are inseparable from ijtihad to find the bill through the understanding and interpretation of requirements. The existence of jurisprudence is used as a basis for the legal considerations of PA judges in completing cases, able to strengthen the strengthening of the law and the resolution of Islamic family law problems fairly and correctly based on the basic principles of Islamic sharia.
\end{abstract}

Keywords: Jurisprudence, Law Enforcement, Islamic Family Law 


\begin{tabular}{llrr}
\hline \hline Volume: & 3 & E-ISSN: & $2655-1942$ \\
Number: & 1 & Terbitan: & April 2020 \\
Page : & $1-14$ & & \\
\hline
\end{tabular}

\section{A. Latar Belakang Masalah}

Yurisprudensi merupakan keputusan hakim tertinggi terhadap suatu perkara yang diikuti oleh hakim dibawahnya dalam menyelesaikan kasus yang sama. Yurisprudensi adalah produk hakim Mahkamah Agung (MA) dalam menyelesaikan kasus hukum yang dasar hukumnya tidak dijelaskan secara terperinci dalam perundang-undangan. Peranan yurisprudensi menjadikan tugas hakim tidak hanya mengaplikasikan undang-undang saja, tetapi juga bertugas menafsirkan, menggali dan menerapkan perundang-undangan demi menegakkan keadilan dan kebahagian manusia. ${ }^{1}$ Keberadaan yurisprudensi sangat membantu masyarakat untuk mendapatkan kepastian dan keadilan hukum.

Peran yurisprudensi MA sangat penting dalam pembangunan hukum di Indonesia termasuk hukum keluarga Islam (law of familie). Hukum keluarga Islam merupakan hukum yang mengatur relasi manusia dalam keluarga (suami, isteri, anak, dan saudara) yang dimulai dari perkawinan sampai pembagian warisan menurut ajaran Islam. ${ }^{2}$ Hukum keluarga Islam terdiri dari hukum perkawinan Islam, kewarisan Islam, wakaf, infaq, zakat dan shadaqah yang didasarkan pada aturan hukum Islam. Pada perkembangannya, pemberlakuan hukum keluarga Islam, tidak hanya berdasarkan pranata keagamaan saja, namun juga berdasarkan peraturan perundang-undangan yang ditetapkan oleh negara, mengandung kewajiban dan larangan, serta sanksi bagi yang melanggarnya. Hal ini dimulai dari pemberlakukan UU Perkawinan No. $1 / 1974,{ }^{3}$ yang kemudian muncul aturan perundangan yang lain, seperti; PP No. 9/1975 tentang pelaksanaan UU Perkawinan, KHI Inpres No. 1/1991 Buku Pertama tentang Hukum Perkawinan, dan UU No 7/1989 jo UU No. 3/2006 tentang Peradilan Agama. ${ }^{4}$

Sirajudin dalam penelitian yang berjudul Konstruksi Hukum Keluarga Islam Di Indonesia: Analisis terhadap Undang-Undang RI No. 1 Tahun 1974 tentang Perkawinan dan KHI, menjelaskan bahwa hukum keluarga Islam sangat bermanfaat

\footnotetext{
${ }^{1}$ Sudikno Mertokusumo, Penemuan Hukum Sebuah Pengantar, Yogyakarta : Libety, 1996, hal 37.

${ }^{2}$ Wahbah Az-Zuhaili, Fiqh Al-Islam wa Adilatullah, Beirut, dar Al-Fikr, 1989, Jilid VI, hal. 6.

3 Romlah, Pembaruan Hukum Keluarga Islam Di Indonesia Tentang Keabsahan Akad Bagi Wanita Hamil, Jurnal Al-'Adalah Vol. XIII, No. 1, Juni 2016, Fakultas Syariah IAIN Lampung, hal. 26

${ }^{4}$ Yahya Harahap, "Informasi Materi Kompilasi Hukum Islam: Mempositifkan Abstraksi Hukum Islam” dalam Mimbar Hukum, No. 5 Tahun, 1992, UGM Yogyakarta hal. 25).
} 


\begin{tabular}{llrr}
\hline \hline Volume: & 3 & E-ISSN: & $2655-1942$ \\
Number: & 1 & Terbitan: & April 2020 \\
Page : & $1-14$ & & \\
\hline
\end{tabular}

dalam upaya menciptakan kehidupan masyarakat yang harmonis dan tertib, khususnya dalam kehidupan keluarga. Negara Indonesia mengapresiasi hukum keluarga Islam dalam bentuk legislasi hukum Islam, guna memberikan payung dan kepastian hukum bagi umat Islam. ${ }^{5}$

Yurisprudensi MA dalam hukum keluarga Islam merupakan produk hukum Islam yang berasal dari putusan hakim peradilan. Selama ini, banyak sengketa hukum keluarga Islam diselesaikan lewat putusan hakim MA, misalnya; hak asuh anak pasca perceraian, pembagian hak waris anak beda agama, status hubungan biologis ayah terhadap anak luar nikah, wasiat wajibah bagi anak angkat, dan lainnya. Namun, produk putusan hakim MA tersebut banyak menuai pendapat kontraversial, karena secara tektual bertentangan dengan aturan dasar hukum keluarga Islam, sehingga menimbulkan reaksi di masyarakat. Pendapat kontra atas putusan hakim MA, menilai bahwa putusan hakim tersebut sangat mengganggu eksistensi pemberlakuan hukum keluarga Islam di masyarakat, bahkan menciderai keadilan hukum.

Eko Setiawan, dalam penelitian yang berjudul Dinamika Pembaharuan Hukum Keluarga Islam Di Indonesia, menjelaskan bahwa hukum keluarga Islam mengalami perkembangan yang sangat signifikan, oleh karena itu sangat diperlukan pembaharuan hukum keluarga Islam yang tidak melanggar syariat/hukum Islam. Pembaharuan hukum keluarga Islam (Islamic Family of Law) yang tidak sesuai dengan syariah/hukum Islam adalah bentuk kesalahan, meskipun tujuannya untuk membentuk kemashlahatan dan menegakkan keadilan. ${ }^{6}$ Dengan demikian eksistensi yurisprudensi MA sebagai salah satu bentuk produk hukum dalam penyelesaian sengketa hukum perkawinan perlu diuji apakah sesuai dengan syariat Islam atau tidak.

Berdasarkan penjelasan di atas, apabila dipahami, terdapat legal issue (permasalahan hukum) yakni pertentangan antara aturan hukum keluarga Islam yang terdapat dalam perundang-undangan (Das Sollen) dengan yurisprudensi MA dalam penetapan sengketa hukum keluarga Islam yang menimbulkan kontraversial karena

\footnotetext{
${ }^{5}$ Sirajudin, Konstruksi Hukum Keluarga Islam Di Indonesia:Analisis terhadap Undang-Undang RI No. 1 Tahun 1974 tentang Perkawinan dan KHI, Jurnal Hukum Islam Istimbath, Vol. 14, No. 2, Desember 2015, hal. 174.

${ }^{6}$ Eko Setiawan, Dinamika Pembaharuan Hukum Keluarga Islam Di Indonesia, de Jure, Jurnal Syariah dan Hukum, Volume 6 Nomor 2, Desember 2014, hal. 147
} 


\begin{tabular}{llrr}
\hline \hline Volume: & 3 & E-ISSN: & $2655-1942$ \\
Number: & 1 & Terbitan: & April 2020 \\
Page : & $1-14$ & & \\
\hline
\end{tabular}

bertentangan dengan aturan hukum keluarga Islam secara tekstual (Das Sein). Oleh karena itu penelitian tentang penegakkan hukum keluarga Islam melalui yurisprudensi MA sangat penting dan layak dilakukan. Rumusan masalahnya adalah sejauhmanakah eksistensi yurisprudensi Mahkamah Agung dapat menegakkan hukum keluarga Islam di Indonesia?

Tujuan penelitian ini untuk menganalisis eksistensi yurisprudensi Mahkamah Agung dalam upaya menegakkan aturan hukum keluarga Islam (Islamic Family of Law) bagi masyarakat Indonesia. Manfaatnya dapat diketahui sejauhmanakah eksistensi yurisprudensi Mahkamah Agung dapat menegakkan hukum keluarga Islam di Indonesia.

\section{B. Metode Penelitian}

Jenis penelitian ini library research, mengambil data perpustakaan yang membahas tema penelitian, yaitu yurisprudensi MA, penegakan hukum dan hukum keluarga Islam. Metode pendekatannya yuridis doktrinal, pendekatan yuridis ${ }^{7}$ artinya metode pendekatan yang berusaha meneliti tentang dasar atau pedoman hukum keluarga Islam, misalnya; UU Perkawinan No.1/1974, dan aturan pelaksanaannya, KHI Inpres No. 1/1991 Buku I tentang aturan perkawinan bagi orang Islam dan UU No.3/2006 tentang Peradilan Agama (PA). Pendekatan doktrinal yaitu pendekatan penelitian yang berupaya meneliti aturan hukum keluarga Islam dan penegakan hukumnya. Penelitian ini memerlukan data sekunder, yang terdiri dari bahan hukum primer (regulasi hukum keluarga Islam), sekunder (literature yang berhubungan dengan kajian hukum) dan tersier (literature yang berkaitan dengan bahan non hukum). Pengumpulan datanya menggunakan studi dokumentasi dan studi pustaka (bahan bacaan). Data yang sudah dikumpulkan akan dianalisis dengan menggunakan kalimat/kualitatif, logika hukum deduktif (dari khusus ke umum), interpretasi/penafsiran hukum atas perundangundangan dan makna hukum, serta deskriptif analitis (analisis dari data pemaparan hasil penelitian). Metode pengolahan data dikerjakan melalui identifikasi dan mengorganisir

\footnotetext{
${ }^{7}$ Kornelius Benuf and Muhamad Azhar, 'Metodologi Penelitian Hukum Sebagai Instrumen Mengurai Permasalahan Hukum Kontemporer', Gema Keadilan, 7.1 (2020), 20-33.
} 


\begin{tabular}{llrr}
\hline \hline Volume: & 3 & E-ISSN: & 2655-1942 \\
Number: & 1 & Terbitan: & April 2020 \\
Page : & $1-14$ & & \\
\hline
\end{tabular}

data, kemudian menkonsep dan mensintesa data, selanjutnya dilakukan analisis dan edit, dan yang terakhir adalah menyimpulkan data.

\section{Hasil Penelitian dan Pembahasan}

Pada pembahasan ini akan dijelaskan tentang yurisprudensi dan penegakan hukum keluarga Islam.

\section{Yurisprudensi}

Kata Yurisprudensi berasal dari bahasa Latin yurisprudentia, artinya pengetahuan hukum (rechtsgeleerdheid). Menurut bahasa Prancis, disebut dengan istilah yurisprudentie, artinya peradilan tetap atau bukan peradilan. ${ }^{8}$ Menurut istilah, yurisprudensi adalah hasil produk peradilan/keputusan hakim yang dapat digunakan dasar bagi hakim pengadilan tingkat pertama, dalam memutuskan perkara hukum serupa, hakim di sini adalah hakim peradilan tertinggi yakni MA. ${ }^{9}$ Yurisprudensi menjadi sumber hukum hakim lain dalam memutuskan kasus serupa, sehingga mempunyai kekuatan hukum.

Landasan yuridis bagi yurisprudensi adalah Pasal 27 ayat (1) Undang-Undang Nomor 14 Tahun 1970 Jo. Pasal 28 ayat (1) Undang-Undang No. 4 Tahun 2004 yang menjelaskan bahwa "Hakim sebagai penegak hukum dan keadilan wajib menggali, mengikuti, dan memahami nilai-nilai hukum yang hidup dalam masyarakat" Pasal tersebut menjelaskan bahwa hakim dalam menjalankan kewenangan absolutnya boleh menggunakan sumber legalitas perundang-undangan berikut tafsirannya dan sumber yang berupa nilai-nilai hukum yang dipatuhi oleh masyarakat. ${ }^{10}$

Yurisprudensi dilakukan dengan menggunakan metode penafsiran dan penemuan hukum untuk mengisi kekosongan hukum dan menyelesaikan sengketa hukum supaya tidak meresahkan masyarakat. Eksistensi yurisprudensi sangat membantu para hakim dalam menangani perkara hukum yang diajukan kepadanya, sementara perundangundangan belum jelas mengaturnya. Kewenangan yurisprudensi adalah para hakim

\footnotetext{
${ }^{8}$ R. Soeroso, Pengantar Ilmu Hukum, Jakarta, Sinar Grafika, 1993, hal. 159

${ }^{9}$ Ibid, hal. 160 .

${ }^{10}$ Cik Hasan Bisri, Hukum Peradilan Agama di Indonesia, Jakarta, Raja Grafindo Persada, 2011, hal 253
} 


\begin{tabular}{llrr}
\hline \hline Volume: & 3 & E-ISSN: & 2655-1942 \\
Number: & 1 & Terbitan: & April 2020 \\
Page : & $1-14$ & & \\
\hline
\end{tabular}

Mahkamah Agung yang berkedudukan di Ibu Kota Jakarta. ${ }^{11}$ Hal ini dikarenakan hakim Mahkamah Agung adalah hakim tertinggi yang bertugas menerima perkara terakhir dari kasasi yang diajukan pemohon atau penggugat untuk memperoleh keadilan dan perlindungan hukum sebagaimana yang diharapkan.

\section{Hukum Keluarga Islam}

Hukum keluarga Islam berasal dari kata hukum keluarga dan Islam. Hukum keluarga (law of famalie), artinya seperangkat aturan yang mengatur hubungan hukum antar anggota keluarga, baik dalam hubungan kekeluargaan sedarah/senasab atau hubungan kekeluargaan karena sebab perkawinan. ${ }^{12}$ Islam di sini maksudnya hukum keluarga yang berdasarkan ajaran Islam. Abdul Wahhab Khallaf berpendapat bahwa hukum keluarga Islam disebut dengan istilah al-ahwal as-syakhsiyah, yaitu aturan yang mengatur hubungan antar anggota keluarga, yang dimulai dari akad nikah sebagai awal keluarga, supaya hubungan antar anggota keluarga harmonis dan dapat menyelesaikan permasalahan keluarga. ${ }^{13}$ Berdasarkan penjelasan di atas memahamkan bahwa hukum keluarga Islam merupakan hukum atau kaidah yang mengatur perbuatan yang dilakukan antar anggota keluarga supaya tujuan pembentukan keluarga tercapai dan tidak melanggar prinsip-prinsip syariah.

Ruang lingkup hukum keluarga Islam meliputi hukum perkawinan (munakahat) termasuk hak asuh anak dan perwalian, hukum kewarisan (mawaris), di dalamnya ada penggunaan harta untuk infaq, shadaqah, zakat dan wakaf. ${ }^{14}$ Hukum keluarga Islam termasuk bagian hukum Islam yang membahas tentang permasalahan keluarga, termasuk penyelesaian sengketa keluarga. Tujuan pembentukan hukum keluarga Islam tentunya untuk menegakkan syariah Islam, tercipta masyarakat tertib, teratur dan damai, bisa menyelesaian sengketa keluarga, bisa mengharmonisasikan dan merukunkan seluruh anggota keluarga. ${ }^{15}$ Selain itu, juga untuk menyeimbangkan hubungan atau

\footnotetext{
${ }^{11}$ Undang-Undang Mahkamah Agung No. 14 Tahun 1985 Pasal 3.

12 Khoiruddin Nasution, Pengantar Dan Pemikiran Hukum Keluarga (Perdata) Islam Indonesia, Yogyakarta: ACAdeMIA+TAZZAFA, 2010, hal. 5-7

${ }^{13}$ Abdul Wahhab Khallaf, 'Ilmu Ushul Al-Fiqh, Kairo, Maktabah Al-Dakwah Al-Islamiyah, t.th, Cet. 8, hal. 32.

${ }^{14}$ Nor Salam, Pembaharuan Hukum Keluarga Islam Melalui Putusan Mahkamah Konstitusi (Studi Analisis terhadap Putusan MK No. 46/PUU-VIII/2010, Tesis, UIN Malang, 2010, hal.66.

${ }^{15}$ Sirajudin, Op. Cit., hal. 174.
} 


\begin{tabular}{llrr}
\hline \hline Volume: & 3 & E-ISSN: & 2655-1942 \\
Number: & 1 & Terbitan: & April 2020 \\
Page : & $1-14$ & & \\
\hline
\end{tabular}

relasi suami dan isteri, bisa memelihara keselamatan anak sekaligus memberikan hak atau kebutuhan anak, seperti; kasih-sayang, pendidikan, kesehatan, dan tumbuh kembang anak.

Dasar hukum keluarga Islam berasal dari wahyu Allah, yakni; Al-Qur'an, AlHadist, dan ijtihad ulama yang berupa; UU Perkawinan No. 1/1974 aturan pelaksanaannya (PP. No. 9/1975), UU No. 7/1989 jo UU No. 3/2006 tentang Peradilan Agama, KHI Inpres No. 1/1991 tentang Perkawinan, Kewarisan dan Wakaf, UU Wakaf No. 41/2004, PP. No. 62/2006 aturan pelaksanaan wakaf, UU Zakat dan PP nya. Pemerintah banyak menetapkan regulasi yang mengatur hukum keluarga Islam karena sangat dibutuhkan orang Islam sebagai umat mayoritas.

\section{Eksistensi Yurisprudensi Mahkamah Agung dalam Penegakan Hukum Keluarga Islam di Indonesia}

Yurispudensi merupakan hasil penemuan atau kreasi hukum dari keputusan/penetapan pengadilan, di mana yurisprudensi adalah produk pemikiran hukum Islam yang berasal dari keputusan peradilan yang dilakukan hakim berdasarkan pemeriksaan di depan persidangan. ${ }^{16}$ Secara teknis keputusan pengadilan disebut dengan istilah al-qadla' atau al-hukm, yaitu hukum yang berasal dari penetapan atau keputusan dari lembaga peradilan (al-wilayah al-qadha'). Ada juga yang mendefinisikan bahwa al-qadla' atau al-hukm adalah hukum Islam yang berasal dari ketatapan/keputusan hakim yang bertugas menyelesaikan suatu perkara di peradilan. ${ }^{17}$ Menurut parameter yang ideal, kedudukan hakim sama derajadnya sebagai seorang mujtahid atau mufti, karena sama-sama menetapkan dan menegakkan hukum Islam, yang dapat digunakan rujukan bagi hakim lain dalam menetapkan kasus atau perkara yang sama.

Peran hakim sangat penting dalam penegakkan hukum Islam, hakim tidak terlepas dari ijtihad, terutama ijtihad tatbiqi, ${ }^{18}$ yakni ijtihad yang berasal dari usaha hakim dalam

\footnotetext{
${ }^{16}$ Abdul Wahhab Khallaf, Op. Cit., hal. 8.

${ }^{17}$ Muhammad Salam Madzkur, al-Qadla'u fi al-Islam, terj. Imron A.M., Peradilan dalam Islam, Surabaya: Bina Ilmu, 1990, hal 20.

${ }^{18}$ Ibid., hal. 130.
} 


\begin{tabular}{llrr}
\hline \hline Volume: & 3 & E-ISSN: & 2655-1942 \\
Number: & 1 & Terbitan: & April 2020 \\
Page : & $1-14$ & & \\
\hline
\end{tabular}

menerapkan hukum Islam, guna menyelesaikan perkara yang dihadapinya secara adil dan memuaskan kepada para pihak pencara keadilan. Ijtihad hukum Islam, tidak boleh dilakukan oleh setiap muslim, namun harus dilakukan oleh mujtahid yang telah memenuhi syarat dan mempunyai otoritas serta kompetensi dalam menetapkan hukum Islam. Selain itu, penetapan hukum Islam juga harus dilaksanakan sesuai dengan prosedur atau kaidah yang dibenarkan oleh syara'. ${ }^{19}$ Secara umum wilayah ijtihad meliputi dua hal, yakni hukum yang tidak atau belum ada aturan dalam nash dan hukum yang dhanni (tidak pasti dan membutuhkan penafsiran). Sedangkan hukum-hukum yang telah ditunjuk oleh nash qath'i (pasti dan jelas), maka tidak diperbolehkan untuk berijtihad. Menurut Abdul Wahhab Khallaf menjelaskan bahwa semangat berijtihad pada nash qath'i telah dikristalkan dalam sebuah kaidah fiqh, yakni; la masagha lil ijtihad fima fih nash sharih qath' $i$, artinya tidak diperbolehkan usaha untuk berijtihad dari apa yang telah diterangkan pada dalil yang pasti dan jelas (qath'i). ${ }^{20}$ Dengan demikian hakim boleh berijtihad atau mengeluarkan yurisprudensi pada masalah dhanny, yang belum dijelaskan secara jelas dalam perundang-undangan dan membutuhkan penafsiran.

Ijtihad hakim merupakan upaya hakim dalam menetapkan perkara yang ditanganinya berdasarkan makna atau tafsir perundang-undangan, karena karakteristik suatu perkara, di mana suatu perkara mesti memiliki karaktertistik tertentu. Hasil ijtihad inilah yang disebut yurisprudensi, artinya memiliki kekuatan hukum tetap dan dapat digunakan dasar hukum hakim lain ketika menangani kasus sama. Latar belakang hakim melakukan ijtihad atau yurisprudensi adalah sebagaimana dijelaskan dalam UU No. 4 Tahun 2004 Pasal 16 tentang Kekuasaan Kehakiman yakni; "Pengadilan tidak boleh menolak untuk memeriksa, mengadili, dan memutus suatu perkara yang diajukan dengan dalih bahwa hukum tidak ada atau kurang jelas, melainkan wajib untuk memeriksa dan mengadilinya". Pasal di atas menjelaskan tentang kedudukan hakim sebagai penegak keadilan, tidak diperbolehkan menolak perkara yang diajukan oleh

\footnotetext{
${ }^{19}$ Abdul Manan, Aspek-aspek Pengubah Hukum, Jakarta: Prenada Media, 2005, hal. 225.

${ }^{20}$ Islamiyati dkk, Penegakan Hukum Perkawinan Islam Melalui Yurisprudensi Mahkamah Agung, Jurnal Majalah Hukum Nasional No. 2/2018, Badan Pembinaan Hukum Nasional, Kementrian Hukum dan Hak Asasi Manusia, Jakarta, hal. 101.
} 


\begin{tabular}{llrr}
\hline \hline Volume: & 3 & E-ISSN: & $2655-1942$ \\
Number: & 1 & Terbitan: & April 2020 \\
Page : & $1-14$ & & \\
\hline
\end{tabular}

masyarakat, dengan alasan aturannya tidak lengkap dan tidak jelas. Namun, hakim harus mampu menemukan hukum dari setiap perkara yang diajukan kepadanya. Oleh karena itu, yang patut dilakukan hakim dalam menyelesaikan perkara di peradilan adalah;

1. Hakim memposisikan perkara dalam proporsi yang tepat dan benar.

2. Selanjutnya hakim mengkonfirmasikan dengan melihat aturan dalam perundangundang;

- Apabila ada aturan perundang-undangannya, maka perkara diadili menurut aturan perundang-undang.

- Apabila undang-undang kurang jelas atau kurang sempurna, maka hakim melakukan penafsiran dibalik bunyi teks perundang-undangan.

- Apabila belum atau tidak ada aturan perundang-undangannya, maka hakim melakukan konstruksi hukum, rechtsverfijning, atau argumentum a contrario.

3. Upaya hakim lainnya, dapat mengkonfirmasikan perkara yang diadili dengan melihat yurisprudensi dan dalil-dalil hukum teks keagamaan, hukum adat atau hukum lokal yang berlaku di dalam masyarakat. ${ }^{21}$

Bertitik tolak dari paparan di atas, dapat dijelaskan bahwa tujuan yurisprudensi adalah untuk menggali dan merumuskan hukum guna menyelesaikan perkara dengan penuh keadilan, menegakkan hukum di masyarakat dan tidak meresahkan warga masyarakat. Oleh karena itu ketentuan ijtihad hakim sehingga menghasilkan yurisprudensi hukum Islam didasarkan pada keadaan berikut :

1. Dalil teks wahyu adalah kitab hukum yang sempurna, maka tugas manusia bukan menciptakan hukum, namun menjelaskan dan memerinci hukum Allah untuk kehidupan manusia. Oleh karena itu tugas hakim adalah memerinci, menggali, merumuskan dan menemukan hukum yang ada dalam wahyu Allah sebagai sumber utama. Selain itu hakim juga berwenang mengaktualkan penerapan wahyu Allah sehingga dapat menjadi hukum yang hidup (living law) di masyarakar.

2. Wahyu Allah dalam menjelaskan ajaran Islam atau substansi hukum lebih banyak menggunakan pendekatan mujmal atau global, artinya hanya penjelasan umum, prinsip-prinsip, atau ada bunyi ayat yang sulit dipahami, menimbulkan arti ganda,

${ }^{21}$ Abdul Manan, Op.Cit., hal. 92-93. 


\begin{tabular}{llrr}
\hline \hline Volume: & 3 & E-ISSN: & $2655-1942$ \\
Number: & 1 & Terbitan: & April 2020 \\
Page : & $1-14$ & & \\
\hline
\end{tabular}

mengandung filosofi yang mendalam, ada maksud tersembunyi di balik bunyi dalil teks, sehingga sangat diperlukan upaya penafsiran.

3. Menghadapi hal tersebut hakim harus diberi kebebasan untuk melakukan upaya guna menemukan hukum, misalnya; melalui kajian heurmenetika atau kajian interpretasi/penafsiran perundangan-undangan yang disesuaian dengan kondisi perkembangan sosial. Terlebih apabila belum ada yurisprudensi, maka hakim layak diberi kebebasan dalam penerapan hukum Islam. ${ }^{22}$

Ijtihad hakim yang disebut yurisprudensi merupakan upaya hakim untuk melakukan pembaharuan hukum keluarga Islam, guna mensinkronisasikan antara ajaran fiqh dengan perkembangan keadaan masyarakat Indonesia, karena hukum akan selalu menyertai kehidupan manusia. Fiqh yang merupakan hasil pemikiran hukum Islam dari para ulama jaman dulu, juga perlu direaktualisasikan dan direkonstruksi supaya dapat menyelesaikan permasalahan hukum keluarga Islam di jaman sekarang. Sehingga hukum bisa ditegakkan dan sesuai dengan tujuannya, yakni memberikan kedamaian, keteraturan, ketertiban dan kebahagiaan masyarakat.

Hukum keluarga Islam telah mengalami pembaharuan hukum sejak diundangkannya Kompilasi Hukum Islam Inpres No.1 Tahun 1991 untuk menyelesaian persoalan hukum keluarga Islam di Indonesia. KHI merupakan kompilasi/kumpulan hukum Islam, yang berfungsi untuk memperbaharui hukum keluarga Islam melalui penyatukan persepsi para imam madhab dalam menyelesaikan persoalan hukum keluarga Islam di masyarakat, yang disesuaikan dengan budaya Indonesia yang tidak bertentangan dengan Al-Quran dan Al-Hadist. ${ }^{23}$ Keberadaan KHI akan mendorong hakim untuk berijtihad dalam menyelesaikan perkara di peradilan, sehingga terbentuk yurisprudensi. Yurisprudensi inilah yang bisa digunakan sebagai dasar pertimbangan hukum bagi hakim lain dalam menyelesaikan kasus serupa, karena KHI merupakan

\footnotetext{
${ }^{22}$ Ibid., hal. 208-209. Abdul Manan dalam Islamiyati dkk, Op. Cit., hal. 101-102.

${ }^{23}$ Abdurrahman, Kompilasi Hukum Islam, (Jakarta: Akademika Pressindo, 2007), hal.. 2-3.
} 


\begin{tabular}{llrr}
\hline \hline Volume: & 3 & E-ISSN: & $2655-1942$ \\
Number: & 1 & Terbitan: & April 2020 \\
Page : & $1-14$ & & \\
\hline
\end{tabular}

perpaduan produk hukum antara hukum keluarga Islam dengan struktur sosial masyarakat Indonesia. $^{24}$

Yurisprudensi yang merupakan salah satu pembaharuan hukum keluarga Islam bertujuan untuk mencapai tujuan pembentukan hukum Islam yakni membawa kemashlahatan dengan tetap memelihara agama, jiwa, akal, harta dan nasab. Hal itu dilakukan demi menegakkan keadilan. ${ }^{25}$ Asas kemashlahatan selalu dilakukan demi menegakkan keadilan hukum keluarga Islam, keduanya hendaknya selalu diimplementasikan oleh hakim dalam menetapkan yurisprudensi. ${ }^{26}$ Dengan demikian eksistensi yurisprudensi dapat menegakkan keadilan dalam penerapan hukum keluarga Islam.

Eksistensi putusan hakim MA yang disebut yurisprudensi terhadap hukum keluarga Islam di Indonesia adalah ${ }^{27}$ :

1. Yurisprudensi berkedudukan sebagai salah satu acuan pertimbangan hakim bagi hakim tingkat pertama dalam memutuskan perkara yang berkaitan dengan hukum keluarga Islam.

2. Yurisprudensi dapat menampilkan kekuatan berikut penjelasan tentang aturan hukum keluarga Islam karena perbedaan penafsiran/interpretasi hukum.

3. Mampu mengukuhkan hukum agama (Islam) sebagai tolak ukur dalam menyelesaikan permasalahan hukum keluarga.

4. Mampu mengarahkan dan memberikan petunjuk tentang problem solving hukum keluarga Islam melalui pendekatan harmonisasi antara hukum negara dan hukum agama.

Berdasarkan penjelasan di atas, dapat dipahami bahwa eksistensi yurisprudensi MA ternyata dapat digunakan sebagai salah satu metode pembaharuan hukum keluarga

\footnotetext{
${ }^{24}$ Romlah, Pembaruan Hukum Keluarga Islam Di Indonesia Tentang Keabsahan Akad Bagi Wanita Hamil, Jurnal Al-'Adalah Vol. XIII, No. 1, Juni 2016, hal. 36.

${ }^{25}$ Mohamad Abdun Nasir, Membedah Anatomi Pembaharuan Hukum Islam Di Indonesia, Jurnal Istinbath, No. 2 Vol. 1 Juni 20014, hal. 206-207.

${ }^{26}$ Ahmad Khoirul Fata \& Mustofa, Menyoal Kontekstualisasi Hukum Islam Tentang Poligami, Jurnal Al-Ulum Volume. 13 Nomor 2, Desember 2013, hal 415 - 434.

${ }^{27}$ Islamiyati, Implikasi Yuridis Putusan Mahkamah Konstitusi No. 68/PUU/XII/2014 Terhadap Penyelundupan Hukum Nikah Beda Agama dalam Perspektif Hukum Islam, Tesis, MIH UNDIP, Semarang, 2016, h. 234.
} 


\begin{tabular}{llrr}
\hline \hline Volume: & 3 & E-ISSN: & $2655-1942$ \\
Number: & 1 & Terbitan: & April 2020 \\
Page : & $1-14$ & & \\
\hline
\end{tabular}

Islam. Alasannya, karena hukum selalu berkembang sesuai dengan konstruksi kondisi dan pemikiran masyarakat. Selain itu, yurisprudensi yang merupakan hasil penemuan hukum hakim MA, juga mampu mengukuhkan penguatan hukum keluarga Islam secara adil dan benar. Pembaharuan hukum keluarga Islam merupakan upaya pembangunan hukum yang berdasarkan prinsip-prinsip dasar hukum Islam yang menegakkan ruh keadilan dan kemashlahatan sebagai cita hukum Al-Magashid Syariah.

\section{Kesimpulan}

Eksistensi yurisprudensi MA dapat menegakkan hukum keluarga Islam, karena dapat menyelesaikan problematika hukum keluarga Islam secara adil di masyarkat. Para pencari keadilan dapat menerima keputusan hakim sesuai yang diharapkan, walaupun secara tekstual ada yurisprudensi yang bertentangan dengan hukum Islam, namun tujuan penetapan tersebut semata-mata untuk memberikan kepastian dan perlindungan hukum serta kemashlahatan. Eksistensi yurisprudensi MA dapat memerankan hukum keluarga Islam sebagai dasar pertimbangan hukum hakim PA dalam menyelesaikan perkara yang sama. Selain itu, juga mampu mengukuhkan penguatan hukum keluarga Islam yang tidak bertentangan dengan nilai-nilai dalam Al-Qur'an dan Al-Hadist yang menegakkan nilai keadilan dan kemashlahatan sebagai cita hukum magashid syariah.

Sarannya adalah yurisprudensi MA diharapkan dapat menegakkan hukum keluarga Islam yang tidak bertentangan dengan prinsip atau kaidah/nilai ajaran Islam yang hidup di masyarakat.

\section{DAFTAR PUSTAKA}

\section{Buku :}

Abdurrahman, 2007, Kompilasi Hukum Islam, Jakarta: Akademika Pressindo.

Ali, Zainuddin, 2006, Hukum Perdata Islam di Indonesia, Jakarta, Sinar Grafika.

Az-Zuhaili, Wahbah, 1989, Fiqh Al-Islam wa Adilatullah, Beirut, dar Al-Fikr, Jilid VI

Daud Ali, Muhammad, 1997, Hukum Islam dan Peradilan Agama, Jakarta, Raja Grafindo Persada. 


\begin{tabular}{llrr}
\hline \hline Volume: & 3 & E-ISSN: & 2655-1942 \\
Number: & 1 & Terbitan: & April 2020 \\
Page : & $1-14$ & & \\
\hline
\end{tabular}

Hasan Bisri, Cik, 2011, Hukum Peradilan Agama di Indonesia, Jakarta, Raja Grafindo Persada.

Khallaf, Abdul Wahhab, t.th, 'Ilmu Ushul Al-Fiqh, Kairo, Maktabah Al-Dakwah AlIslamiyah.

Manan, Abdul, 2005, Aspek-aspek Pengubah Hukum, Jakarta: Prenada Media.

Mertokusumo, Sudikno, 1996, Penemuan Hukum Sebuah Pengantar, Yogyakarta : Libety.

Nasution, Khoiruddin, 2010, Pengantar Dan Pemikiran Hukum Keluarga (Perdata) Islam Indonesia, Yogyakarta: ACAdeMIA+TAZZAFA.

R. Soeroso, 1993, Pengantar Ilmu Hukum, Jakarta, Sinar Grafika.

Salam Madzkur, Muhammad, 1990, al-Qadla'u fi al-Islam, terj. Imron A.M., Peradilan dalam Islam, Surabaya: Bina Ilmu.

Salam, Nor, 2010, Pembaharuan Hukum Keluarga Islam Melalui Putusan Mahkamah Konstitusi (Studi Analisis terhadap Putusan MK No. 46/PUU-VIII/2010, Tesis, UIN Malang.

\section{Jurnal Nasional :}

Benuf, Kornelius, and Muhamad Azhar, 'Metodologi Penelitian Hukum Sebagai Instrumen Mengurai Permasalahan Hukum Kontemporer', Gema Keadilan, 7.1 (2020).

Eko Setiawan, Dinamika Pembaharuan Hukum Keluarga Islam Di Indonesia, de Jure, Jurnal Syariah dan Hukum, Volume 6 Nomor 2, Desember 2014, ISSN 20851618, UIN Maulana Malik Ibrahim, Malang.

Harahap, M. Yahya, 1992, "Informasi Materi Kompilasi Hukum Islam: Mempositifkan Abstraksi Hukum Islam" Jurnal Mimbar Hukum, No. 5 Tahun, 1992, UGM Yogyakarta.

Fata, Ahmad Khoirul, \& Mustofa, 2013, Menyoal Kontekstualisasi Hukum Islam Tentang Poligami, Jurnal Al-Ulum Volume. 13 Nomor 2, Desember 2013.

Islamiyati, 2016, Implikasi Yuridis Putusan Mahkamah Konstitusi No. 68/PUU/XII/2014 Terhadap Penyelundupan Hukum Nikah Beda Agama dalam Perspektif Hukum Islam, Tesis, MIH UNDIP, Semarang, 2016.

----------, 2013, Diskresi Pada Penegakkan Hukum Di Peradilan Agama Semarang, Jilid 47 No.3. ISSN 2086-2695, Prosiding Seminar Nasional Hukum Islam, September 2012, FH UNDIP Semarang.

Nasir, Mohamad Abdun, Membedah Anatomi Pembaharuan Hukum Islam Di Indonesia, Jurnal Istinbath, No. 2 Vol. 1 Juni 20014. 


\begin{tabular}{llrr}
\hline \hline Volume: & 3 & E-ISSN: & $2655-1942$ \\
Number: & 1 & Terbitan: & April 2020 \\
Page : & $1-14$ & & \\
\hline
\end{tabular}

Romlah, 2016, Pembaruan Hukum Keluarga Islam Di Indonesia Tentang Keabsahan Akad Bagi Wanita Hamil, Jurnal Al-‘Adalah Vol. XIII, No. 1, Juni 2016, Fakultas Syariah IAIN Lampung.

Sirajudin, 2015, Konstruksi Hukum Keluarga Islam Di Indonesia:Analisis terhadap Undang-Undang RI No. 1 Tahun 1974 tentang Perkawinan dan KHI, Jurnal Hukum Islam Istimbath, Vol. 14, No. 2, Desember 2015.

\section{Perundang-undangan :}

\section{UUD NKRI 1945}

UU No. 14/1970 jo UU No. 35/1999 tentang Pokok-Pokok Kekuasaan Kehakiman

UU No. 14/1985 Tentang Mahkamah Agung

Undang-Undang No. 4 Tahun 2004

\section{Web-side:}

www.penegakanhukumislam.com, diakses pada tanggal 2 Februari 2020, jam 16.00 www.yurisprudensihakim,com., diakses pada tanggal 2 Februari 2020, jam 17.05 WIB 